\title{
Effects of the addition of direct-fed microbials and glycerol to the diet of lactating dairy cows on milk yield and apparent efficiency of yield
}

\author{
J. Boyd, ${ }^{1}$ J. W. West, and J. K. Bernard \\ Department of Animal and Dairy Science, The University of Georgia, Tifton 31793
}

\begin{abstract}
A study was conducted to evaluate the effects of a direct-fed microbial $(\mathrm{M})$ and dietary glycerol $(\mathrm{G})$ on milk yield, efficiency of yield, and nutrient digestibility during hot weather. Sixty Holstein cows averaging 120 $\mathrm{d}$ in milk (DIM) and $36.2 \mathrm{~kg} / \mathrm{d}$ of milk were used in a 12 -wk $2 \times 2$ factorial design trial from June through September 2008. Cows were fed a common diet during the 2-wk standardization period and were blocked by milk yield, DIM, parity, and dry matter intake. Diets were based on corn and ryegrass silages and balanced to be isocaloric and isonitrogenous. Treatments included a negative control (M- or G-), $4 \times 10^{9} \mathrm{cfu} /$ head of a combination of Lactobacillus acidophilus NP51 and Propionibacterium freudenreichii NP24 (M+), control plus $400 \mathrm{~g} / \mathrm{h}$ per day of $99 \%$ pure food-grade glycerol $(\mathrm{G}+)$, and $4 \times 10^{9} \mathrm{cfu} / \mathrm{h}$ per day of a combination of Lactobacillus acidophilus NP51 and Propionibacterium freudenreichii NP24 plus $400 \mathrm{~g} / \mathrm{h}$ per day of $99 \%$ pure food-grade glycerol $(\mathrm{MG}++)$. No interactions were observed between direct-fed microbials and dietary glycerol in the study except on apparent nutrient digestibility. No differences were observed in dry matter intake, which averaged 22.7, 23.1, 23.4, and 22.9 for $\mathrm{M}-, \mathrm{G}-, \mathrm{M}+$, and $\mathrm{G}+$, respectively. Milk yield was increased for $\mathrm{M}+$ compared with $\mathrm{M}-$ at 34.1 and 31.7 $\mathrm{kg} / \mathrm{d}$, but $\mathrm{G}+$ had no effect on yield. No treatment effect was noted for milk fat percentage or milk protein percentage among diets. Milk protein yield was higher for $\mathrm{M}+$ compared with $\mathrm{M}-$ at 0.93 versus $0.87 \mathrm{~kg} / \mathrm{d}$. Energy-corrected milk was improved for the $\mathrm{M}+$ versus $\mathrm{M}-$ groups at 33.5 and $31.6 \mathrm{~kg} / \mathrm{d}$, respectively. No differences in respiratory rate, skin temperature, body temperature, or concentrations of serum glucose or urea $\mathrm{N}$ were observed among treatments. Improvement in apparent digestibility was observed with $\mathrm{M}+$ and $\mathrm{G}+$ compared with $\mathrm{M}-/ \mathrm{G}-$ in this experiment. The addition of a direct-fed microbial alone improved milk and protein yield, energy-corrected milk, and apparent
\end{abstract}

Received November 3, 2010.

Accepted May 25, 2011.

${ }^{1}$ Corresponding author: jamie.boyd@ars.usda.gov digestibility of crude protein, neutral detergent fiber, and acid detergent fiber, and the inclusion of glycerol $(\mathrm{G}+)$ had a positive effect on apparent dry matter and acid detergent fiber digestibility compared with $\mathrm{M}-$ / $\mathrm{G}-$. The addition of a direct-fed microbial and dietary glycerol may improve yield and digestibility for cows subject to heat stress.

Key words: dietary glycerol, direct-fed microbial, efficiency

\section{INTRODUCTION}

Direct-fed microbials (DFM) were defined as a source of live, naturally occurring microorganisms by Krehbiel et al. (2003) and they are used in the dairy industry to improve cow performance, feed efficiency, and health (Yoon and Stern, 1995). These products can be marketed as a natural feed additive and the inclusion of DFM in dairy cow diets has become a generally accepted practice according to Nocek and Kautz (2006). A review by Krehbiel et al. (2003) reported that supplementation with DFM increased ADG 2.5 to 5\% and improved feed efficiency in feedlot cattle by $2 \%$. Other researchers (Nocek and Kautz, 2006; Weiss et al., 2008; West and Bernard, 2011) conducting studies with lactating dairy cows reported improved milk yields and efficiency with the inclusion of dietary bacterial inoculants. Various strains of Propionibacterium increased the molar proportion of ruminal propionate (Kim et al., 2000; Stein et al., 2006). The effect of feeding Propionibacterium alone or in combination with other bacteria to dairy cows has been evaluated but results have been inconsistent. The primary bacterial organisms fed to ruminants are Lactobacillus acidophilus and Propionibacterium freudenreichii. Feeding these organisms together may be beneficial because L. acidophilus are lactate-producing bacteria and $P$. freudenreichii are lactate-utilizing bacteria that produce propionate as a product of fermentation.

Previous research (Reynolds et al., 1994; Huntington, 2000 ) estimated that propionate accounted for 61 to $67 \%$ of the glucose release in growing ruminants and lactating dairy cows. Feeding a DFM containing a lactate-producing organism such as L. acidophilus in combination with $P$. freudenreichii could be beneficial 
by providing greater concentrations of substrate for propionate production and possibly greater glucose concentrations leading to improved animal performance. Performance improvements may be a result of the modification of the rumen or lower gut microbial population, alteration of ruminal fermentation patterns, increased intestinal nutrient flow, improved diet digestibility, and improved immune function (Yoon and Stern, 1995; Krehbiel et al., 2003).

The second area of focus in this study was the effect of including glycerol in the diet. The growth of the ethanol industry has increased the need for alternatives to corn in lactating cow diets. This industry growth is expected to increase availability and promote favorable pricing of glycerol. Glycerol is a byproduct of basecatalyzed transesterification of oil in the formation of methyl and ethyl fatty acid esters in the production of biodiesel (Thompson and He, 2006) and is a main byproduct of ethanol fermentation processing (Michnick et al., 1997). According to the FDA (2006), glycerol is recognized as a safe feed ingredient in animal diets. Several studies have reported that glycerol enhances rumen fermentation and improves feed efficiency (Garton et al., 1961; Dirksen et al., 1985; Remond et al., 1993; Schröder and Südekum, 1999; Linke et al., 2004; Hippen et al., 2008). Dietary glycerol seems to be extensively fermented to propionate by ruminal bacteria (Czerkawski and Breckenridge, 1972; Remond et al., 1993; Bergner et al., 1995), although level of feeding and method of delivery may affect the amount of glycerol that escapes fermentation (Kijora et al., 1998; DeFrain et al., 2004).

The increased availability may create an opportunity to use glycerol as a future energy source in dairy rations and has led to a corresponding decline in price projections (Yazdani and Gonzalez, 2007). These changes may favor the use of glycerol in rations fed to livestock, especially with the rising corn costs and more crops being diverted to biofuel production. Glycerol has also been shown to improve the hydration state of horses by stimulating renal water conservation and enhancing voluntary water intake (Schott et al., 2001). In humans and rats, a single dose of glycerol may increase body water up to $5 \%$ (Koenigsberg et al., 1995). Osborne et al. (2009) reported increased water intake in transition cows when glycerol was added to the drinking water at $20 \mathrm{~g} / \mathrm{L}$. If glycerol acts to enhance the hydration state in dairy cows as it does in other species, it may prove beneficial in animals during heat stress and other stress conditions.

The effects of including DFM and low levels of glycerol in the diet of high-production dairy cows under heat stress conditions have not been evaluated or only in limited situations. Therefore, the objective of this study was to evaluate the effects of the addition of DFM and low levels of dietary glycerol separately and in combination on DMI, milk yield, blood metabolites, and apparent efficiency of high-yielding dairy cows during heat stress conditions.

\section{MATERIALS AND METHODS}

The study was conducted during the summer of 2008 at the University of Georgia Tifton Campus Dairy Research Center. The average environmental temperature in the barn during the study was $25.6^{\circ} \mathrm{C}$, with a low of $17.4^{\circ} \mathrm{C}$ and a high of $35.1^{\circ} \mathrm{C}$. Protocols for the trial were approved by the University of Georgia Institutional Animal Care and Use Committee.

\section{Cows and Management}

Sixty mid-lactation primiparous $(\mathrm{n}=29)$ and multiparous $(\mathrm{n}=31)$ Holstein cows (15 per treatment) were used in a 12 -wk $2 \times 2$ factorial design study. The study included a 2-wk standardization period followed by a 10 -wk experimental period. Cows averaged $120 \pm$ 12 DIM, $35.8 \pm 0.5 \mathrm{~kg} / \mathrm{d}$ of milk, $3.62 \pm 0.23 \%$ milk fat, $2.78 \pm 0.08 \%$ milk protein, and $41.2 \pm 1.2 \mathrm{~kg} / \mathrm{d}$ of ECM at the end of the standardization period. Cows were housed in a freestall barn with access to individual freestalls and were fed behind Calan doors (American Calan Inc., Northwood, NH). Training for Calan door use was initiated in May, the 2-wk standardization period ran from June 12 to 28 , and the treatment period began on July 3 and continued through September 9 . Supplemental cooling was provided by a combination of fans and high-pressure misters.

Diets were balanced to be isocaloric and isonitrogenous and based on corn and ryegrass silages (Table 1). Diets were mixed and fed once daily for ad libitum intake. The amount fed was adjusted daily to achieve orts of 7 to $10 \%$. Dry matter for forage ingredients was determined weekly and adjustments to the TMR were made weekly. Cows were milked twice daily at 0400 and $1500 \mathrm{~h}$, and milk weights recorded electronically at each milking (Alpro Laval, Kansas City, MO) throughout the study. During the 2-wk standardization period, all cows received the control ration and intake, milk yield, and component data were collected for use as a covariate in the statistical analysis of the production data. Cows were blocked by milk yield, DIM, parity, and intake during the standardization period into 15 groups of 4 and assigned randomly to 1 of the 4 experimental diets within block.

\section{Experimental Treatments and Design}

Dietary treatments were arranged as a $2 \times 2$ factorial design. Individual treatments included control $(\mathbf{M}-/$ 
Table 1. Ingredient and chemical composition ( \pm SD) of experimental diets containing supplemental direct-fed microbials and glycerol

\begin{tabular}{lcccc}
\hline & \multicolumn{3}{c}{ Diet $^{1}$} \\
\cline { 2 - 5 } Item & $\mathrm{M}-/ \mathrm{G}-$ & $\mathrm{M}+$ & $\mathrm{G}+$ & $\mathrm{MG}++$ \\
\hline Ingredient (\% of DM) & & & \\
Corn silage & 20.2 & 20.2 & 20.2 & 20.2 \\
Alfalfa hay & 15.5 & 15.5 & 15.6 & 15.6 \\
Ryegrass silage & 12.3 & 12.3 & 12.3 & 12.3 \\
Ground corn & 25.2 & 25.2 & 23.5 & 23.5 \\
Wet brewers grain & 13.1 & 13.1 & 13.1 & 0.79 \\
Megalac & 0.79 & 0.79 & 0.79 & 13.0 \\
Concentrate mix & & & \\
Glycerol & 13.0 & 13.0 & 13.0 & 1.51 \\
Chemical composition (\% of DM) & 0 & 0 & & \\
DM (\%) & $54.4 \pm 1.5$ & $53.0 \pm 2.5$ & $53.4 \pm 2.2$ & $52.8 \pm 1.2$ \\
NDF & $39.8 \pm 0.6$ & $37.8 \pm 0.6$ & $36.0 \pm 0.4$ & $36.2 \pm 1.4$ \\
ADF & $39.1 \pm 0.6$ & $26.7 \pm 0.5$ & $27.5 \pm 0.7$ & $27.5 \pm 0.3$ \\
CP & $17.5 \pm 0.4$ & $17.9 \pm 1.2$ & $17.4 \pm 1.9$ & $18.2 \pm 1.1$ \\
RUP & 3.34 & 3.2 & 3.3 & 3.43 \\
RDP & 14.2 & 14.5 & 14.1 & 14.8 \\
Ether extract & $4.4 \pm 1.43$ & $4.7 \pm 1.0$ & $4.7 \pm 1.3$ & $4.9 \pm 1.0$ \\
\hline
\end{tabular}

${ }^{1} \mathrm{M}-/ \mathrm{G}-=$ no microbial or glycerol included; $\mathrm{M}+=$ direct-fed microbial; $\mathrm{G}+=400 \mathrm{~g} /$ head per day of glycerol; MG++ = direct-fed microbial plus $400 \mathrm{~g} /$ head per day of glycerol. Samples were collected $2 \times$ weekly and compiled by week for analysis $(\mathrm{n}=10)$.

${ }^{2}$ Church and Dwight Co. Inc., Princeton, NJ.

${ }^{3}$ Composition of concentrate mix (\% of DM): $2.04 \%$ ProLak (H. J. Baker and Bro. Inc., Westport, CT); $6.06 \%$ soybean meal 48; $0.151 \%$ Ca 17; P 21\%; $0.182 \% \mathrm{~K}$-Mg-sulfate; $0.454 \% \mathrm{~K}_{2} \mathrm{CO}_{3} ; 0.151 \%$ limestone; $0.151 \%$ urea $45 \% \mathrm{~N} ; 0.027 \%$ Availa- $4 ; 0.154 \% \mathrm{MgO} ; 0.227 \%$ salt; $0.530 \% \mathrm{Na}$ bicarbonate; $0.188 \%$ yeast; $0.121 \%$ trace mineral premix; $0.01 \%$ vitamin premix; 0.229\% Rumensin 3 (3 g of Rumensin per kilogram of feed; Elanco, Greenfield, IN).

${ }^{4}$ Calculated using NRC (2001).

G-) with no additives, control plus $400 \mathrm{~g} /$ head of glycerol $(\mathbf{G}+)$, control plus live bacterial inoculant ( $\mathbf{M}+)$, and live bacterial inoculant plus $400 \mathrm{~g} / \mathrm{d} / \mathrm{h}$ of glycerol $(\mathbf{M G}++)$; diets are detailed in Table 1 . The DFM (Bovamine, Nutrition Physiology Corp., St. Cloud, $\mathrm{MN}$ ) was added according to manufacturer's instructions at a concentration of $4 \times 10^{9} \mathrm{cfu} / \mathrm{h} / \mathrm{d}$ of a proprietary blend of Lactobacillus acidophilus NP51 and Propionibacterium freudenreichii NP24 mixed with $1 \mathrm{~kg}$ of ground corn daily in a kitchen mixer and individually top dressed onto the TMR for each cow for treatments $\mathrm{M}$ and $\mathrm{MG}$. The $\mathrm{M}-$ and $\mathrm{G}+$ treatments were individually top dressed with $1 \mathrm{~kg}$ of ground corn daily. The topdress was mixed into the TMR with a shovel after it was added. To prevent any cross contamination, shovels used for mixing $\mathrm{M}+$ diets were not used to mix $\mathrm{M}-/ \mathrm{G}$ - diets. Production data from 2 cows from the $\mathrm{G}$ - diet were excluded from the final analysis because of reduced production due to mastitis infections.

\section{Data Collection}

The amount of feed offered and refused was recorded daily, and daily adjustments were made to maintain a 7 to $10 \%$ daily refusal rate. Milk yield was recorded and summed daily. Milk samples were collected from 2 consecutive milkings each week and analyzed for milk fat and protein percentage and somatic cell count by the Southeast Milk Inc. Laboratory (Bell, FL). Energycorrected milk was calculated using the following equation: $\mathrm{ECM}=(0.327 \times \mathrm{kg}$ of milk $)+(12.95 \times \mathrm{kg}$ of fat $)+(7.65 \times \mathrm{kg}$ of protein) (Reid and Tyrrell, 1965).

Individual body temperatures were recorded every 15 min for 4 consecutive days during standardization and during wk 6 and 10 of the treatment period using intravaginal probes (HOBO Water Temperature Pro, Onset Corp., Contoocook, NH) attached to blank EaziBreed controlled internal drug-release devices (CIDR; InterAg, Hamilton, New Zealand) to obtain individual cow temperatures. Environmental temperature data collected by HOBO environmental monitors (HOBO Temperature Pro, Onset Corp.) mounted over the freestall area in the barn recorded the daily minimum and maximum ambient temperatures throughout the study. Cows were weighed weekly using electronic scales, following the p.m. milking and before access to feed or water.

Blood samples from the coccygeal vein were collected once during the standardization period and during wk 6 and 10 of the treatment period for analysis of se- 
rum glucose and urea $\mathrm{N}$ at the University of Georgia Veterinary Diagnostic Laboratory (Tifton, GA) using a Boehringer Mannheim/Hitachi 912 automated chemistry analyzer (Roche Laboratory Systems, Indianapolis, IN).

Feed and ingredient samples were collected twice per week and composited by week for analysis. The DM content was determined by drying in a forced-air oven at $55^{\circ} \mathrm{C}$ for $48 \mathrm{~h}$. Samples were ground using a Wiley mill (Arthur H. Thomas, Philadelphia, PA) to pass through a 1-mm screen for analysis of DM, NDF, ADF, $\mathrm{CP}$, and ether extract (AOAC, 1990). The Ankom ${ }^{200}$ fiber system (Ankom Technology Corp., Fairport, NY) was used for sequential analysis of NDF and ADF (Van Soest et al., 1991). Samples were analyzed for NDF using sodium sulfite and $\alpha$-amylase (A3306, Sigma Chemical Co., St Louis, MO).

\section{Nutrient Digestibility}

Nutrient digestibility of diets was determined on a subset of 48 cows on wk 9 of the experimental period. Cows were fed $23 \mathrm{~g} / \mathrm{d}$ (DM basis) of $\mathrm{Cr}_{2} \mathrm{O}_{3}$ mixed into the experimental diet for $10 \mathrm{~d}$ before a 4 -d collection period. Powdered $\mathrm{Cr}_{2} \mathrm{O}_{3}$ was mixed with ground corn as a carrier at a rate of $3.82 \mathrm{~g} / \mathrm{kg}$ of corn on a DM basis in an upright mixer. The $\mathrm{Cr}_{2} \mathrm{O}_{3}$-corn blend was then added to the TMR wagon, and diets were mixed as normal. Daily feed and ort samples were collected during the 4-d collection period. Fecal grab samples were taken during the collection period at 12 -h intervals, with the collection time advancing by $3 \mathrm{~h}$ each day (0300, 0600, 0900, 1200, 1500, 1800, 2100, and 2400 h). Fecal samples were frozen at $-5^{\circ} \mathrm{C}$ until being composited by cow. Samples of feed, orts, and feces were dried at $55^{\circ} \mathrm{C}$, ground to pass through a 1-mm screen using a Wiley mill, and stored for later chemical analysis.

Diets, orts, fecal samples, and ingredient samples were analyzed for $\mathrm{DM}, \mathrm{NDF}, \mathrm{ADF}$, and $\mathrm{CP}$ using procedures defined earlier. Chromium content of feed, orts, and feces was determined using atomic absorption spectrophotometry (AAnalyst 100/300, Perkin Elmer, Bellefontaine, PA) following wet ashing (Ferret et al., 1999).

\section{Statistical Analysis}

Data were analyzed as a $2 \times 2$ factorial design using PROC Mixed procedures of SAS version 9.1 (SAS Institute, 2004). Significance was defined as $P<0.05$ and tended to differ if $0.05 \leq P \leq 0.10$. Interactions that were nonsignificant $(P>0.65)$ were excluded from the final model for all data sets. Values reported are least squares means and associated standard errors.
Experimental model 1 was used for the intake, production, and net energy data. Interactions tested were $M$ $\times \mathrm{G}, \mathrm{M} / \mathrm{G} \times$ week, and $\mathrm{M} / \mathrm{G} \times$ day, but were excluded from the final model because of nonsignificance. The experimental model (2) for blood components, respiratory rates, and body temperatures included block, period, and treatment. Interaction tested was period $\times$ $\mathrm{M} / \mathrm{G}$. Cow within treatment was included as a random variable for models 1 and 2 and day was included as a repeated measure for model 1 . No interactions between treatments with additives were observed for intake, production, energy balance, or blood samples, so only main effect data has been presented in this paper. The covariate (pre-treatment: DMI and milk yield, components, blood components, respiratory rates, and body temperatures) data was tested to determine significance in models 1 and 2 and was excluded from the final analysis if nonsignificant. The data in the apparent digestibility sub-trial did display interactions for the $M \times$ $\mathrm{G}$ interaction; therefore, pairwise $t$-tests with Tukey's adjustment were performed between treatment means, using the PDIFF statement in SAS. The experimental model [3] for apparent digestibility included block and treatment. Cow within treatment was included as a random variable for model [3]:

$$
\begin{gathered}
Y_{i j k l m n}=\mu+K_{l}+W_{m}+D_{k}+\alpha_{i}+\beta_{j}+e_{i j k l m n}, \\
Y_{i j k l m}=\mu+K_{l}+P_{k}+\alpha_{i}+\beta_{j}+\alpha \beta P_{i j m}+e_{i j k l m}, \\
Y_{i j k l}=\mu+K_{l}+\alpha_{i}+\beta_{j}+\alpha \beta_{i j}+e_{i j k l,},
\end{gathered}
$$

where $Y_{i j k l m n}, Y_{i j k l m}$, and $Y_{i j k l}=$ variable response; $\mu=$ general mean; $\alpha_{i}=$ fixed effect of $\mathrm{M}(i=0,1) ; \beta_{j}=$ fixed effect of $\mathrm{G}(j=0,1) ; K_{l}=$ fixed effect of block $(l=$ $1 \ldots 15) ; W_{m}=$ fixed effect of week $(\mathrm{m}=1 \ldots 0) ; D_{k}=$ fixed effect of day $(k=1 \ldots 70) ; P_{k}=$ fixed effect of pe$\operatorname{riod} k=1 \ldots 3) ; \alpha \beta_{i j}=$ interaction of $\mathrm{M}$ and $\mathrm{G} ; \alpha \beta P_{i j m}$ $=$ interaction of period and treatment; and $e_{i j k l m n}, e_{i j k l m}$, and $e_{i j k}=$ residual error.

\section{RESULTS AND DISCUSSION}

The chemical and ingredient composition of diets is presented in Table 1. The diets were balanced to be isocaloric and isonitrogenous at the beginning of the study.

No differences were observed in DMI among treatments, but milk yield was improved for $\mathrm{M}+$ compared with $\mathrm{M}-(P<0.004)$ at 34.1 and $31.7 \mathrm{~kg} / \mathrm{d}$, respectively (Table 2). This is in agreement with previous studies that reported milk yield was increased when supplemental $P$. freudenreichii (de Ondarza and Seymour, 
2008 ) or P. freudenreichii plus L. acidophilus (West and Bernard, 2011) was fed. Nocek and Kautz (2006) reported that transition dairy cows supplemented with DFM products produced more milk during the preand postpartum periods. A tendency $(P<0.06)$ for increased protein $(\mathrm{kg} / \mathrm{d})$ was noted for $\mathrm{M}+$ compared $\mathrm{M}-$. No effect was seen on milk fat or protein percentage among diets. This is consistent with previous studies that reported no effect on milk composition with the inclusion of $P$. freudenreichii plus L. acidophilus in the diet (Raeth-Knight et al., 2007; Weiss et al., 2008). Donkin and Doane (2007) replaced ground corn with 99.5\% pure glycerol and corn gluten feed at 0, 5, 10, and $15 \%$ of the dietary DM and reported no effect on milk yield or composition. In a transition cow study, Chung et al. (2007) fed a dried glycerol product (food grade, $65 \%$ glycerol) and reported no difference in subsequent milk yield or composition.

Energy-corrected milk was improved $(P<0.03)$ for $\mathrm{M}+$ compared with $\mathrm{M}-$ at 33.5 and $31.6 \mathrm{~kg} / \mathrm{d}$, but efficiency was not affected by the addition of $\mathrm{M}+$ or $\mathrm{G}+$ to the diet (Table 2). Improved milk yield in the absence of greater DMI suggests that rumen function was improved through improved digestion, modified ruminal environmental conditions, or greater microbial protein yield. Francisco et al. (2002) reported that early-lactation cows fed $17 \mathrm{~g}$ of Propionibacterium culture (strain identified as P169 and supplemented at approximately $6 \times 10^{10} \mathrm{cfu} / \mathrm{d}$ ) consumed less DM and produced similar amounts of milk as the control group. A subsequent study (Stein et al., 2006) demonstrated that early lactation, multiparous cows offered $6 \times 10^{10}$ or $6 \times 10^{11} \mathrm{cfu} / \mathrm{d}$ of Propionibacterium strain P169 produced about $8 \%$ more FCM than the control cows, but no difference was observed among the primiparous cows. The present results agree with Donkin et al. (2009) who reported that overall feed efficiency (milk yield/DMI) did not differ among treatments $(0$,
5,10 , or $15 \%$ of dietary glycerol), but the calculated partial efficiency of feed for BW gain was increased in a linear manner with increasing glycerol in the diet. Similarly, Linke et al. (2004) reported that including glycerol at $498 \mathrm{~g}$ and $998 \mathrm{~g}$ in the diet of mid-lactation Holstein and Brown Swiss cows had no effect on DMI, milk yield, or FCM, but those authors did note an improvement in feed efficiency with the inclusion of glycerol, with milk:feed ratios of $1.46,1.59$, and 1.60 for the control, $498 \mathrm{~g}$ of glycerol, and $998 \mathrm{~g}$ of glycerol, respectively.

No differences among treatments were observed for net energy balance, BW change, or blood metabolites (Table 3). Body temperatures were recorded on wk 6 and 10 of the treatment period and were not significantly different among treatments or by period (data not shown). Apparent ruminal digestion of forage DM was increased in cows supplemented with dietary glycerol (Table 4) for $\mathrm{G}+$ versus $\mathrm{G}-(P<0.01)$ at 70.8 and $67.3 \%$, respectively. The inclusion of $(\mathrm{M}+)$ DFM $(70.3 \%)$ in the diet increased $(P<0.03)$ apparent $\mathrm{CP}$ digestibility compared with $\mathrm{M}-/ \mathrm{G}-(65.6 \%)$ and an improvement for $\mathrm{G}+(69.1 \%)$ and $\mathrm{MG}++(69.6 \%)$ was observed compared with $\mathrm{M}-/ \mathrm{G}-$. Apparent digestibility of ADF was improved $(P<0.002)$ for $\mathrm{G}+(56.6 \%)$ compared with $\mathrm{M}+(53.5 \%)$ and $\mathrm{MG}++(49.2 \%)$. Apparent NDF digestibility was increased $(P<0.0005)$ for $\mathrm{M}+(61.4 \%)$ versus $\mathrm{M}-/ \mathrm{G}-(56.8 \%)$ and $\mathrm{MG}++$ $(56.6 \%)$. Present results are in contrast to work by Raeth-Knight et al. (2007) who used mid-lactation cows to determine the effects on milk yield, nutrient digestibility, and rumen fermentation of Lactobacillus acidophilus and Propionibacterium freudenreichii. Supplementing mid-lactation dairy cows with these microbes had no effect on apparent nutrient digestibility or rumen fermentation. However, the P169 strain of Propionibacterium increased propionate production of cannulated steers without having an effect on feed

Table 2. Performance of lactating Holstein cows fed diets supplemented with direct-fed microbial and dietary glycerol ${ }^{1,2}$

\begin{tabular}{|c|c|c|c|c|c|c|c|c|}
\hline Item & \multicolumn{2}{|c|}{ M } & $\mathrm{SE}$ & $P<$ & \multicolumn{2}{|c|}{$\mathrm{G}$} & $\mathrm{SE}$ & $P<$ \\
\hline DMI (kg/d) & 22.7 & 23.4 & 0.56 & 0.37 & 23.1 & 22.9 & 0.56 & 0.80 \\
\hline Fat $(\%)$ & 3.56 & 3.50 & 0.09 & 0.63 & 3.62 & 3.44 & 0.10 & 0.20 \\
\hline Fat $(\mathrm{kg} / \mathrm{d})$ & 1.13 & 1.18 & 0.04 & 0.41 & 1.17 & 1.14 & 0.04 & 0.56 \\
\hline Protein $(\%)$ & 2.79 & 2.78 & 0.03 & 0.93 & 2.83 & 2.74 & 0.04 & 0.15 \\
\hline Efficiency (milk yield/DMI) & 1.44 & 1.48 & 0.04 & 0.53 & 1.43 & 1.49 & 0.04 & 0.38 \\
\hline
\end{tabular}

\footnotetext{
${ }^{1} \mathrm{M}-=$ no microbial; $\mathrm{M}+=$ direct-fed microbial; $\mathrm{G}-=$ no glycerol; $\mathrm{G}+=400 \mathrm{~g} /$ head per day of glycerol.

${ }^{2}$ No significant interaction $(P>0.55)$ for MG (direct-fed microbial $+400 \mathrm{~g} /$ head per day of glycerol) was observed, so only main effects are reported in this table. No significant treatment $\times$ week interactions were observed during this study.

${ }^{3}$ Two cows in treatment $\mathrm{G}$ - were excluded from the final production analysis due to severe mastitis infection.
} 
Table 3. Net energy balance of lactating Holstein cows fed diets supplemented with a direct-fed microbial and or dietary glycerol ${ }^{1,2}$

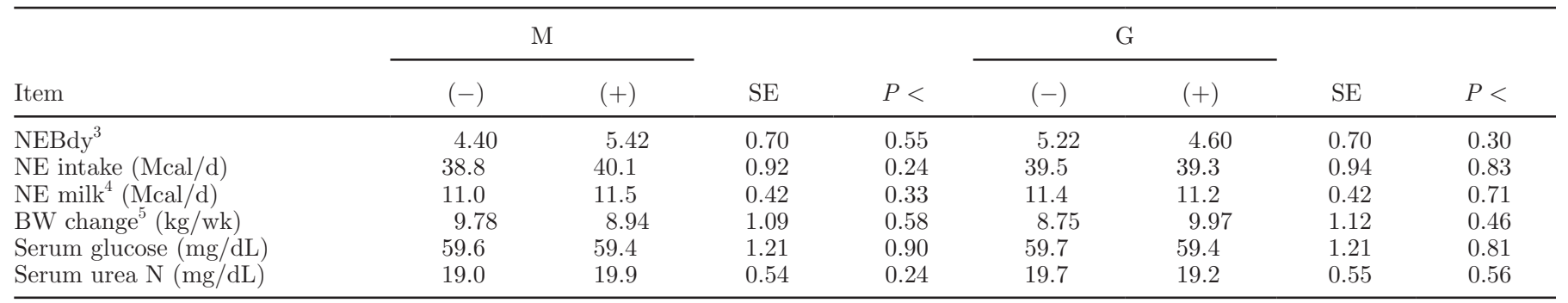

${ }^{1} \mathrm{M}-=$ no microbial; $\mathrm{M}+=$ direct-fed microbial; $\mathrm{G}-=$ no glycerol; $\mathrm{G}+=400 \mathrm{~g} /$ head per day of glycerol.

${ }^{2}$ No significant interaction $(P>0.55)$ for MG (direct-fed microbial $+400 \mathrm{~g} /$ head per day of glycerol) was observed, so only main effects are reported in this table. No period $\times$ diet interactions were observed for serum glucose or blood urea $\mathrm{N}$.

${ }^{3} \mathrm{NEBdy}=[\mathrm{NE}$ balance per week $=\mathrm{NE}$ intake $(\mathrm{Mcal} / \mathrm{d})-\mathrm{NE}$ maintenance $(\mathrm{Mcal} / \mathrm{d}) \pm \mathrm{NE}$ of tissue change $(\mathrm{Mcal} / \mathrm{d})-\mathrm{NE}$ of milk $(\mathrm{Mcal} / \mathrm{d})] / 7$ (NRC, 2001).

${ }^{4} \mathrm{NE}$ milk $=$ milk $(\mathrm{kg} / \mathrm{d}) \times[(0.0929 \times$ milk fat $\%)+(0.0563 \times$ milk protein $\left.\%)+0.192)\right](\mathrm{NRC}, 2001)$.

${ }^{5} \mathrm{BW}$ change $=$ difference $(+$ or -$)$ in BW by week.

intake, duodenal flow, microbial $\mathrm{N}$ synthesis, or ruminal kinetics (Lehloenya et al., 2008). Work by other researchers (Kim et al., 2000; Stein et al., 2006) also demonstrated that various strains of Propionibacterium affect ruminal fermentation by increasing the molar proportions of ruminal propionate. Weiss et al. (2008) conducted a study to determine the effect of Propionibacterium strain P169 fed at $6 \times 10^{11} \mathrm{cfu} / \mathrm{d}$ on rumen fermentation, milk yield, and health of periparturient and early lactation cows. The calculated energy expenditures for maintenance, milk yield, and BW change were similar among treatments, but cows offered the microbial supplement had a lower DMI, resulting in a $4.4 \%$ increase in the efficiency of converting dietary DM to milk yield. They attributed this improvement to ruminal fermentation patterns by decreasing acetate and increasing propionate levels.

\section{CONCLUSIONS}

Inclusion of the DFM Lactobacillus acidophilus NP51 and Propionibacterium freudenreichii NP24 in the ration of high-yielding dairy cows improved milk and protein yield and ECM, and improved apparent digestibility of dietary nutrients. Addition of dietary glycerol with DFM improved apparent DM and ADF digestibility compared with the control. The effects of the DFM may be due to changes in ruminal fermentation and improved ruminal efficiency. In conclusion, the addition of a DFM and low levels of dietary glycerol alone or in combination may improve performance and efficiency in high-yielding dairy cows. Further research is needed to determine the ruminal fermentation effects of DFM and the optimum levels of dietary glycerol in the ruminant diet on improving efficiency.

Table 4. Apparent digestibility for lactating Holstein cows fed diets supplemented with a direct-fed microbial and or dietary glycerol

\begin{tabular}{|c|c|c|c|c|c|c|}
\hline \multirow[b]{2}{*}{ Item } & \multicolumn{4}{|c|}{$\operatorname{Diet}^{1}$} & \multirow[b]{2}{*}{$\mathrm{SE}$} & \multirow[b]{2}{*}{$P<<^{2}$} \\
\hline & $\mathrm{M}-/ \mathrm{G}-$ & $\mathrm{M}+$ & $\mathrm{G}+$ & $\mathrm{MG}++$ & & \\
\hline \multicolumn{7}{|l|}{ Intake $(\mathrm{kg} / \mathrm{d})$} \\
\hline DM & 20.5 & 22.8 & 22.7 & 23.8 & 1.04 & 0.57 \\
\hline $\mathrm{CP}$ & 3.5 & 4.1 & 3.9 & 4.3 & 0.19 & 0.62 \\
\hline $\mathrm{ADF}$ & 6.0 & 6.0 & 6.2 & 6.5 & 0.29 & 0.67 \\
\hline NDF & 9.0 & 10.1 & 9.7 & 10.2 & 0.45 & 0.50 \\
\hline \multicolumn{7}{|l|}{ Digestibility (\%) } \\
\hline DM & $67.3^{\mathrm{a}}$ & $70.3^{\mathrm{ab}}$ & $70.8^{\mathrm{b}}$ & $69.1^{\mathrm{ab}}$ & 0.91 & 0.01 \\
\hline $\mathrm{CP}(\%$ of $\mathrm{DM})$ & $65.6^{\mathrm{a}}$ & $70.3^{\mathrm{b}}$ & $69.1^{\mathrm{b}}$ & $69.6^{\mathrm{b}}$ & 0.94 & 0.03 \\
\hline $\mathrm{ADF}(\%$ of $\mathrm{DM})$ & $51.5^{\mathrm{ab}}$ & $53.5^{\mathrm{b}}$ & $56.6^{\mathrm{a}}$ & $49.2^{\mathrm{b}}$ & 1.4 & 0.002 \\
\hline $\mathrm{NDF}(\%$ of $\mathrm{DM})$ & $56.8^{\mathrm{bc}}$ & $61.4^{\mathrm{a}}$ & $61.2^{\mathrm{ab}}$ & $56.6^{\mathrm{c}}$ & 1.22 & 0.0005 \\
\hline
\end{tabular}

${ }^{\mathrm{a}-\mathrm{c}}$ Means with unlike subscripts in the same row are significantly different $(P<0.05)$.

${ }^{1} \mathrm{M}-/ \mathrm{G}-=$ no microbial or glycerol included; $\mathrm{M}+=$ direct-fed microbial; $\mathrm{G}+=400 \mathrm{~g} / \mathrm{head}$ per day of glycerol; $\mathrm{MG}++=$ direct-fed microbial plus $400 \mathrm{~g} /$ head per day of glycerol.

${ }^{2}$ The interaction $(\mathrm{M}+\times \mathrm{G}+)$ was significant for nutrient digestibility, so the means and significance for the interaction are presented in this table. 


\section{ACKNOWLEDGMENTS}

The authors thank Nutrition Physiology Corporation (St. Cloud, MN) for sponsoring this study. The authors also thank the employees at the University of Georgia Dairy Research Center for their help with animal care and sample collection and to Melissa Tawzer and Melanie Renney for their laboratory and technical assistance.

\section{REFERENCES}

AOAC. 1990. Official Methods of Analysis. 15th ed. Association of Official Analytical Chemists, Washington, DC.

Bergner, H., C. Kijora, Z. Ceresnakova, and J. Szakacs. 1995. In vitro studies on glycerol transformation by rumen microorganisms. Arch. Tierernahr. 48:245-256.

Chung, Y. H., D. E. Rico, C. M. Martinez, T. W. Cassidy, V. Noirot, A. Ames, and G. A. Varga. 2007. Effects of feeding dry glycerin to early postpartum Holstein cows on lactational performance and metabolic profiles. J. Dairy Sci. 90:5682-5691.

Czerkawski, J. W., and G. Breckenridge. 1972. Fermentation of various glycolytic intermediates and other compounds by rumen microorganisms, with particular reference to methane production. Br. J. Nutr. 27:131-146.

de Ondarza, M. B., and W. M. Seymour. 2008. Effect of propionibacteria supplementation on yield of milk and milk components of dairy cows. Prof. Anim. Sci. 24:254-259.

DeFrain, J. M., A. R. Hippen, K. F. Kalscheur, and P. W. Jardon. 2004. Feeding glycerol to transition dairy cows: Effects on blood metabolites and lactation performance. J. Dairy Sci. 87:41954206

Dirksen, G. U., H. G. Liebich, and E. Mayer. 1985. Adaptive changes of the ruminal mucosa and their functional and clinical significance. Bovine Pract. 20:116-120.

Donkin, S., and P. Doane. 2007. Glycerol as a feed ingredient for dairy cows. Tristate Nutrition Dairy Nutrition Conference. http:// tristatedairy.osu.edu/Proceedings\%202007/Donkin\%20paper.pdf.

Donkin, S. S., S. L. Koser, H. M. White, P. H. Doane, and M. J. Cecava. 2009. Feeding value of glycerol as a replacement for corn grain in rations fed to lactating dairy cows. J. Dairy Sci. 92:5111-5119.

FDA. 2006. Code of Federal Regulations, 21 CFR 582.1320, Title 21 Vol. 6, 21CFR582.1320: Substances Generally Recognized As Safe: General Purpose Food Additives-Glycerin. http://edocket.access. gpo.gov/cfr_2002/aprqtr/21cfr582.1320.htm.

Ferret, A., J. Plaixats, G. Caja, J. Gasa, and P. Prio. 1999. Using markers to establish apparent dry matter digestibility, fecal output and dry matter intake in dairy ewes fed Italian ryegrass hay or alfalfa hay. Small Rumin. Res. 33:145-157.

Francisco, C. C., C. S. Chamberlain, D. N. Waldner, R. P. Wettermann, and J. L. Spicer. 2002. propionibacteria fed to dairy cows: Effects on energy balance, plasma metabolites and hormones, and reproduction. J. Dairy Sci. 85:1738-1751.

Garton, G. A., A. K. Lough, and E. Vioque. 1961. Glyceride hydrolysis and glycerol fermentation by sheep rumen contents. J. Gen. Microbiol. 25:215-225.

Hippen, A. R., J. M. DeFrain, and P. L. Linke. 2008. Glycerol and other energy sources for metabolism and production of transition dairy cows. Page 1 in Proc. 19th Annual Florida Ruminant Nutrition Symposium, Gainesville, FL. Department of Animal Science, University of Florida, Gainesville.

Huntington, G. B. 2000. High-starch rations for ruminant production discussed. Feedstuffs 23:12-13.

Kijora, C., H. Bergner, K. P. Gotz, J. Bartelt, J. Szakacs, and A. Sommer. 1998. Research note: Investigation on the metabolism of glycerol in the rumen of bulls. Arch. Tierernahr. 51:341-348.

Kim, S. W., D. G. Standorf, H. Roman-Rosario, M. T. Yokoyama, and S. R. Rust. 2000. Potential use of Propionibacterium, strain DH42 as a direct- fed microbial for cattle. J. Dairy Sci. 83(Suppl. 1):292. (Abstr.)
Koenigsberg, P. S., K. K. Martin, H. R. Hlava, and M. L. Riedesel. 1995. Sustained hyperhydration with glycerol ingestion. Life Sci. 57:645-653.

Krehbiel, C. R., S. R. Rust, G. Zhang, and S. E. Gillard. 2003. Bacterial direct fed microbials in ruminant diets: Performance response and mode of action. J. Anim. Sci. 81(E. Suppl. 2 ):E120-E132.

Lehloenya, K. V., C. R. Krehbiel, K. J. Mertz, T. G. Rehberger, and L. J. Spicer. 2008. Effects of Propionibacteria and yeast culture fed to steers on nutrient intake and site and extent of digestion. J. Dairy Sci. 91:653-662.

Linke, P. L., J. M. DeFrain, A. R. Hippen, and P. W. Jardon. 2004. Ruminal and plasma responses in dairy cows to drenching or feeding glycerol. J. Dairy Sci. 87(Suppl. 1):343. (Abstr.)

Michnick, S., J. L. Roustan, F. Remize, P. Barre, and S. Dequin. 1997. Modulation of glycerol and ethanol yields during alcoholic fermentation in Saccharomyces cerevisiae strains over expressed or disrupted for GPD1 encoding glycerol 3-phosphate dehydrogenase. Yeast 13:783-793.

Nocek, J. E., and W. P. Kautz. 2006. Direct fed microbial supplementation on ruminal digestion, health and performance of pre and postpartum dairy cattle. J. Dairy Sci. 89:260-266.

NRC. 2001. Nutrient Requirements of Dairy Cattle. 7th rev. ed. Natl Acad. Sci., Washington, DC.

Osborne, V. R., N. E. Odongo, J. P. Cant, K. C. Swanson, and B. W McBride. 2009. Effects of supplementing glycerol and soybean oil in drinking water on feed and water intake, energy balance, and production performance of periparturient dairy cows. J. Dairy Sci. 92:698-707.

Raeth-Knight, M. L., J. G. Linn, and H. G. Jung. 2007. Effect of direct fed microbial on performance, diet digestibility, and rumen characteristics of Holstein dairy cows. J. Dairy Sci. 90:1802-1809.

Remond, B., E. Souday, and J. P. Jouany. 1993. In vitro and In vivo fermentation of glycerol by rumen microbes. Anim. Feed Sci. Technol. 41:121-132.

Reynolds, C. K., D. L. Harmon, and M. J. Cecava. 1994. Absorption and delivery of nutrients for milk protein synthesis by portal drained viscera. J. Dairy Sci. 77:2787-2808.

SAS Institute. 2004. User's Guide: Statistics, Version 9.1 ed. SAS Inst. Inc., Cary, NC.

Schott, H. C., K. S. Patterson, and S. W. Eberhart. 2001. Glycerol hyperhydration in resting horses. Vet. J. 161:194-204.

Schröder, A., and K. Südekum. 1999. Glycerol as a by-product of biodiesel production in diets for ruminants. Proc. 10th International Rapeseed Congress, Canberra, Australia. The Regional Institute Ltd., Gosford, Australia. http://www.regional.org.au/au/ gcirc/1/241.htm\#TopOfPage.

Stein, D. R., D. T. Allen, E. B. Perry, J. C. Bruner, K. W. Gates, T. G. Rehberger, K. Mertz, D. Jones, and L. J. Spicer. 2006. Effects of feeding propionibacteria to dairy cows on milk yield, milk components, and reproduction. J. Dairy Sci. 89:111-125.

Thompson, J. C., and B. He. 2006. Characterization of crude glycerol from biodiesel production from multiple feedstocks. Appl. Eng. Agric. 22:261-265.

Tyrrell, H. F., and J. T. Reid. 1965. Prediction of the energy value of cow's milk. J. Dairy Sci. 48:1215-1223.

Van Soest, P. J., J. B. Robertson, and B. A. Lewis. 1991. Methods for dietary fiber, neutral detergent fiber, non-starch polysaccharides in relation to animal nutrition. J. Dairy Sci. 74:3583-3597.

Weiss, W. P., D. J. Wyatt, and T. R. McKelvey. 2008. Effect of feeding propionibacteria on milk production by early lactation dairy cows. J. Dairy Sci. 91:646-652.

West, J. W., and J. K. Bernard. 2011. Effects of addition of bacterial inoculants to the diets of lactating dairy cows on feed intake, milk yield, and milk composition. Prof. Anim. Sci. 27:122-126.

Yazdani, S. S., and R. Gonzalez. 2007. Anaerobic fermentation of glycerol: A path to economic viability for the biofuels industry. Curr. Opin. Biotechnol. 18:213-219.

Yoon, I. K., and M. D. Stern. 1995. Influence of direct-fed microbials on ruminal microbial fermentation and performance of ruminants: A review. Asian-australas. J. Anim. Sci. 8:533-555. 